\title{
The Effect Of Reading Programmes On Turkish School Libraries
}

\author{
Dr Inci Önal \\ Associate Professor \\ Hacettepe University, Faculty of Letters \\ Department of Information Management \\ Ankara, TURKEY
}

\begin{abstract}
Reading programmes - everyone talks about them, but few Turkish school libraries provide enough of them. The literature consistently points to improved use of them in school libraries, but less than quarter of the librarians feel well prepared to use reading programmes. Many school library collections have insufficient foreign literature and limited representation of different cultures. In order to explore this problem this presentation will include: the history of Turkish children's literature; the children's literature products in Turkish school libraries; the current profile of Turkish school libraries related to reading programmes; and the evaluation of changing needs and increasing demands for books and information.
\end{abstract}

A combination of comprehensive literature review and original research on Turkish children's literature, reading programmes and Turkish school libraries provides the basis for a fresh and in-depth discussion of the increasingly complex relationships between these factors and children's needs.

\section{Introduction}

The design of reading programmes for children and young adults has become extremely important for education and children's and young adults' response to reading programmes has become an active area for study.

Reading may aid in the development of the ideal self. For example, characters in books may serve as useful objects for identification and imitation. If reading influences selfimage, then information on the effect of different kinds of reading material on individuals should be helpful in achieving better personal development through reading. Generally, reading programmes have influenced emergence of: self image, philosophy of life, sensitivity to people, intellectual freedom, emotional responses, educational developments, psychological developments, understanding of cultural groups and social problems. Factors to consider in programme development include physical format of materials, information technology facilities, client profiles, target groups, user feedback and monitoring of requests.

The major purpose of this paper is to assist librarians and teachers to introduce Turkish children's literature and establish reading programmes. The description of various important aspects of these can be very useful for practical consideration, collection development and literary selections assigned for reading. This paper also emphasises the contributions of the reading research literature to understanding of different cultural products. The first section of the review sketches the history of research on Turkish children's literature, which examines authors, publications and general concepts. The second explains the general process of collection development domains and the structure of Turkish school 
libraries. Current reading programmes in Turkish school libraries are then reviewed and effective use of programmes is described. A discussion of promising new avenues of research concludes the presentation.

\section{The history of Turkish children's literature}

The history of the Turkish children's literature goes back thousands years. Rich folk sources such as Karagöz shadowplays, Nasreddin Hodga stories, the Keloglan (Egghead) tales and fairy tales were just a few of the oral tradition products underpinning Turkish children's literature. The first of the new breed of writers for the child was Kayserili Dr Rüstü who dominated the 1850s. Nuhbet'iil Etfal (To the most heautiful child) by Kayserili Dr Rüstï was the first published children's book and included a few translated fables and short stories (Alpay, 1991, p.14; Keyserili, 1959; Tuncer, 1995, p.268). Between 1850 and 1920 , many well-known authors and poets wrote for children. Sinasi, Ahmet Mithat, Tevfik Fikret, Namık Kemal, Ziya Gökalp, Ibrahim Alaaddin Gövsa, Resat Nuri Güntekin, Ahmed Rasim and Ömer Seyfeddin all wrote for children. Their well-known novels, short stories and poetry are still read by children and are now considered as classics.

The Turkish War of Independence (1919-1922) and the major changes from the Arabic alphabet to the Latin alphabet in 1928 were a cause of economic and social change. With the efforts of literary mean, many old favourites and the historical novels of Abdullah Ziya Kozanoglu and Rakim Calapala were transeribed or re-published.

In the 1940s, several very important projects were supported. The Ministry of National Education and Cocuk Esirgeme Kurumu (The Turkish Child Protection Society) sponsored the translation of one hundred children's classics from all parts of the world. These were largely comprised of fairly tales, legends, fables and short stories and gave an impetus to publication of children's literature. The translations of La Fontaine's Fables by the wellknown poet, Orhan Veli Kanik, have been especially popular (Tuncer, 1995, p.268).

In the 1950s, social issues became the preferred subjects. Talip Apaydin, Mehmet Seyda, Gülten Dayioglu, Aziz Nesin, Rifat Ilgaz, Eflatun Cem Güney were popular authors of humorous stories, novels and/or Turkish folk-tales. Publishers like Dogan Kardes and Arkin Kitabevi were the most important companies. These publishers arranged contests for the best storybook of the year and published fine journals as well as good quality books, mostly containing translation from the classics.

In the 1960s, picture books were published using offset printing techniques. Initially most of these were translations from the French (e.g., "Martine" series).

In the late 1970s, publishers began to realise that children's books, publications both high in quality and quantity, were very important. A few publishers like Arkin, Remzi, Milliyet, Arkadas, Redhouse, Altin Kitaplar, Mavibulut, YA-PA have continued to publish good quality books.

Very importantly, by the early 1980 s publishers had learned that the major way in which children respond to their products and children's needs and expectations as regards to literature, was a researchable problem. The Ministry of Culture collaboration with The Ministry of National Education has been of considerable support to Turkish authors. 
Authors whose body of work would make for interesting reading and study for poetry, novels, short stories, fairly tales and picture books include Fazil Hüsnü Daglarca, Mustafa Ruhi Sirin, Serpil Ural, Can Göknil, Ruhsar Belen, Fatih Erdogan (Tuncer, 1995, p.269).

Although many aspects of children's literature have received support since the mid1990s, most children's periodicals have not developed as well as books. In addition to banksponsored periodicals, there are three main journals for children: Milliyet, Tercüman and Türkiye, which are published by newspapers with the same names.

Tuncer (1994), Alpay (1980) and Sirin (1995) have all conducted studies of the children's literature of the World and Turkey and note the growing demand from Turkish teachers and librarians for books that depict Turkish cultural scene.

Authors, librarians and teachers working together can strive to engender a literary culture that is relevant and appealing. It is hoped that the future of Turkish children's books will be good quality with strong products and publications.

\section{The children's literature products in Turkish school libraries}

School library programmes have been developed to provide information and resources, enrich children's minds and imagination, contribute skills development in information handling, establish a trusting relationship with publications, prepare children to become lifelong readers and learners, and teach using new technologies. Children's literature presents to the reader a world, at national, global and trans-national levels, that is easily accessible through, not only the school library programme, but also in their homes. It is known that children's literature is an essential part of a school library programme. The vital importance of reading programmes is limitless. These programmes, however, are not accessible to or utilised by all school library users in Turkey.

This section documents the findings of an investigation into reading programmes and resources undertaken at basic education schools for the $6-14$ year age group and secondary schools for the $15-17$ year age group. The investigation was conducted from January to March of 2004. The major focus is on the findings of a survey of all available school library personnel and/or school librarians, and from a series of interviews with 37 librarians and teacher librarians from different school levels.

The broad objectives of this research were:

- To explain the structure of the Turkish school libraries;

- To conduct research into the reading habits, interests, literary preferences and practices of students;

- To collect evidence of what students in years six to seventeen are reading, in and out of school:

- To provide recommendations for the reading programme, groups, libraries, schools, and the like.

In this section the general structure of Turkish school libraries will be reviewed before the reading interests of children students in levels $6-14$ and $15-17$ years are described. 


\section{Structure of the Turkish school libraries}

School libraries in Turkey go back to the 1700s. They have been traditional institutions since the period of the Ottoman Empire. After the establishment of the Ministry of National Education in 1857, the Turkish education system was reorganised. Under the Law of the Unity of Education, passed on March 3, 1924 (Tevhid-i Tedrisat Kanunu, 1924), it become mandatory to endeavour to unify both liberal and religious education in Turkey. Several researchers and scholars have made great contributions to the development of school libraries in education since 1924.

Turkey gained its the first school library legislation ("By-law of School Libraries") in 1959 (Okul, 1959) which was revised in 1976 (Okul, 1976) and 2001 (Milli, 2001). Basic changes in school librarianship in Turkey have been introduced, but it ean be said that they have some serious problems given the lack of policy, library material resources, qualified librarians, budget, facilities and buildings (Önal, 1995). Despite these problems, every school has a library. (In the 2003-2004 Academic year, there were 42,637 schools with 14,065,815 students in basic education and secondary education institutes (Milli, 2003).) Reading programmes, guiding principles and suggestions have been developed during since 1959.

In Turkey, the biggest proportion of school library collections has been composed of books selected by the Ministry of National Education. However, since the beginning of 2004 , this selection has been made by school librarians and teachers.

\section{Basic education students: Early school-aged children and school-aged children}

Children aged 6 to 8 years start reading books in school. Both the stress of reading development and the social interactions available at school affect the child's literature preferences. Early school-aged children enjoy learning facts, concepts, and skills. They appreciate literature with humour, fantasy, and surprise endings. Books for the beginning reader have one to two sentences on a page. Repetition of words and phrases facilitates early reading efforts and elear, unclutered pictures and drawings promote the identification of words. Where parents wish to buy books for their children, librarians can prepare reading lists to assist them in determining the reading level of any particular example of children's literature.

Between 8 and 14 years of age, children are ready for realistic fiction and non-fiction books. Realistic fiction depicts the events that happen in the real world to characters created by the author. Non-fiction, however, chronicles the events of real people in the real world. School-aged children prefer books about children of the same age. They are learning to make choices and develop a personal set of values. Through identification with the book's characters, the children can experience self-determination, independence, and success. As children advance successfully in school, reading ability improves. The school-aged child can turn from picture books to illustrated books, which rely heavily on the text to tell the story. Complex sentence structure and new words challenge the school-aged child. They can categorise and organise information. They ean also suecessfully extract concrete examples and information from children's literature. Poets and humorous stories are very popular.

Generally, they prefer to use and read books in the school library. In the $2003-2004$ Academic year, in Turkey, there were 36,093 schools with 10,478,671 students in basic 
education institutes (Milli, 2003). Finding books that suit everyone in school library is real problem for basic education students.

A number of printed lists, based on the interest scores of students and available in school library collections have been prepared by 37 librarians and/or teachers who wish to identify well-liked titles for recreational reading to their students. The world classics have been read as class reading. From students' choices for class reading, it appears that librarians as well as teachers are either unaware of, or disregard, differences in the interests of boys and girls. In many cases, while the average interest of boys and girls appears satisfactory, boys" interest scores are much lower than those of the girls. According to a study by the author: novels, short stories, poems and biographies written by Sait Faik Abasiyanik, Talip Apaydin, Fazil Hüsnü Daglarca, Gülten Dayioglu, Eflatun Cem Güney, Resat Nuri Güntekin, Hüseyin Rahmi Gürpinar, Muzaffer Izgu, Orhan Veli Kanik, Omer Seyfeddin, Mustafa Ruhi Sirin, Kemalettin Tugcu, Yalvac Ural, Hüseyin Yurttas have been well-liked literary products.

We have seen many children get stuck in a particular genre or category of book. Using audio-visual materials and interactive publication products is one ways to encourage wider reading. These types of reading materials, especially those produced by Yalvaç Ural, form a very popular and pleasurable book series for children.

\section{Secondary education students: The $15-17$ year age group}

In choosing reading materials in Turkish school libraries for the 15-17 year age group, gender is a universal and highly significant factor. The boys' interests in reading materials, as revealed by the current study, centre on: adventure, sport, technology, patriotism, mystery, obvious humour, and action. For girls, the favoured special interest subjects include humour, adventure without grimness, love, detective and other mysteries, social life, technology, and patriotism.

In the choice of reading materials, boys give a favourable rating on the average to novels, plays, short stories, and biographies of men; while girls rate the same literary types favourably, but also include poems and biographies of women.

A variety of materials will be needed to provide students with appropriate instruction in school libraries. Every student likes the library in his or her school and wants to use it. In the 2003 - 2004 Academic year, there were 6,544 schools with 3,587,144 students in secondary education institutes in Turkey (Milli, 2003 ).

It is true that there have been many reading lists issued by teachers and librarians. The Ministry of National Education does purchase some textbooks each year for students in economic difficulties, but unfortunately, for a wide variety of subjects, resources are scarce. Schools have tried to find funds from parents, foundations, or other sources for several years, but this is an unequal and undependable route to providing school library books. Government can play a key role here. The Government and Ministry of National Education must provide the funds needed to rebuild school libraries and thus increase the practice of reading and the creation of lifelong readers.

The current study, in which 37 librarians and/or teachers participated, undertook to investigate young people's choices of reading materials and individual selections. They include the works of the following authors: Inci Aral, Kursat Basar, Selim Ileri, Yakup Kadri 
Karaosmanoglu, Orhan Kemal, Yasar Kemal, Tuna Kiremitci, Ayse Kulin, Aziz Nesin, Ipek Ongun, Orhan Pamuk, Buket Uzuner. These are also the most favoured authors in Turkey. In general, adult books are more popular with adolescents than are those written specifically for young people.

\section{The current profile of Turkish school libraries related to reading programmes}

According to the literature covering 1923 to 2004, reading programmes were conceived with the overall purpose of making available, to the users of Turkish school libraries, a collection of library materials in a variety of forms, on a wide range of subjects, which meet users' immediate needs and interests. A summary of the guiding principles, reading programmes and suggestions developed during 81 years" study of children and young people's reading is offered below. Specifically, the aim is to:

- acquire materials of every kind which have been selected for incorporation into the library collection

- organise these materials by some comprehensible system to facilitate their use and to insure placing together those items which are common in subject content, form, or some other meaningful characteristic

- provide an easily accessible library facility which will attract the young people

- consider reading readiness at every age level

- serve the informational needs of the young people by maintaining a collection of library materials acceptable to their age and to the times

- encourage maximum use of the library materials by lending for home use on signature

- maintain each item in the collection to insure its continued availability and use

- demonstrate the interest and concern of individuals and organisations in the welfare of the young people

- improve the collections, utilising print, audio-visual and electronic resources, and

- to determine the effect of school library service's concerted effort to encourage voluntary reading, not only through teachers, librarians and guidance counsellors, but with the co-operation of parents.

In addition to the reading programmes shared with associates, every student should have his own reading programme encouraged by parents, teachers, and librarians.

\section{The evaluation of changing needs and increasing demands for books and information}

The school library is an indispensable partner for teachers, especially for Turkish and literature teachers. Generally, students aged six to seventeen do not have aceess to books and periodicals in their homes. Some of them use public libraries, but the facilities of public libraries are very poor. Fortunately, the school library is the most important and unique place to access and use current information resources. School libraries should evaluate reading programmes using circulation statistics and results of interviews with students and teachers. It 
will be better to change and develop the school library reading programmes to reflect the needs of students.

Views of changing needs and the increasing demands for books and information identified in this research include:

- the school library is seen as the most important place for reading programmes, meeting information needs, lifelong learning and enrichment

- everyone wants a well-equipped library in school

- young people's interests change more rapidly than adult's interests

- reading interests are influenced in varying degrees by a variety of factors, such as gender, age or maturity, intelligence, special interest factors, the teaching methods used, the classroom situation, leisure activities, social factors, and current problems

- students need current materials in addition to their textbooks

- science courses and social science courses call for audio-visual materials

- book reading tends to decrease with increased television viewing

- popular interests are always important for users: school libraries must provide timely access to titles and accurate information of current interest to customers, and

- television, Internet, computer games and music media are successful competitors of books, magazines and newspapers.

Students and teachers need access to all materials with co-ordination of school library. It is helpful to know what is required and can be encapsulated in a school library policy for producing the future action plans.

\section{Conclusion}

The development of a programme based on a love of reading will be the most important contribution the school can make to the student's education. Achievement of this purpose would transform the whole programme of in-school and after-school education. There is general agreement that a wide and detailed knowledge of the children's literature and children's and young people's choices of reading materials are deeply affected by the school library services. Students believe that schools should maintain well stocked, arranged, and managed libraries, and work with encouragement of librarians for them. The school library is seen as one of the most important places for motivating children and young people to select, read, access and evaluate, not only printed materials, but also audio-visual and electronic materials. Reading is a significant, social, cultural and recreational activity. School libraries can enhance reading instruction by offering literature-based activities, but without this kind of school library programme and adequate facilities, the student's efforts in developing enjoyment of reading as well as reading skills are to some extent empty.

School librarians should have a good grasp of subject matter - what is taught to students in their schools - and how it relates to the school library. In addition, they need to know how the education system is structured, financed and administered, and they should be aware of new media, including its form and contents. Knowing the students' information 
needs and their lifestyles, as well as the educational process, is essential as media, information, and telecommunications services become intereonnected and converge in information services. The increasingly complex relationship between children's literature and school libraries, reading programmes and changing needs, has developed in the past fifty years. This demands the provision of quality literature-based reading programmes throughout the year and supporting not only governments and institutions, but also communities and individuals.

\section{References}

Alpay, M. (1980). Türk cocuk edebiyati. Gïncy-Dogu Arastirmalari Dergisi. (8-9).167 191 .

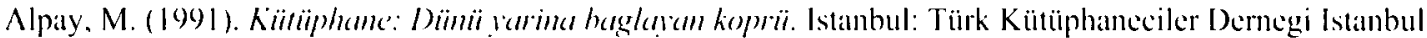
Subesi.

Kayserili, Dr. Rüstï. ( 1859$)$. Nuthher 'äl Etfal. Istanbul: no publisher.

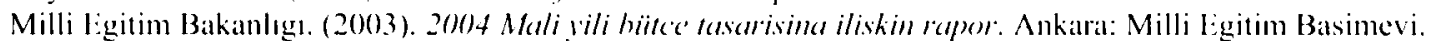

Milli Egitim Bakanlıgl Okul Kütüphancleri Yönetmeligi. (22 August, 200)1). Resmi (jaze'te2450) .

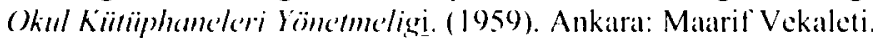

Okul Kütüphancleri Yönetmeliği. (26 August. 1976). Resmi (iaze'le 15689).

Onal. H. I. (1945). School Library Development in Turkey. Tïrk Kïtïphumeciligi. 9(3), 255257.

Sirin. M. R. (1.d.). (1995). 99 Sorruda cocuk edehircati. Istanbul: Cocuk Vakli Yayinlari.

Tevhid-i Tedrisat Kanunu. (1924). (Kanun No. 430). Kabul kuihi: 3 Mart 1924.

Tuncer, N. (1994). (izgi roman re cocuk. Istanbul: Cocuk Vakli Yayinlari

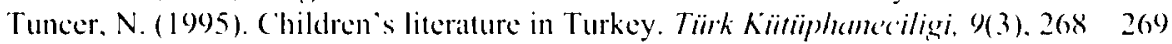

\section{Author Note}

Dr Önal is an Associate Professor at Hacettepe University, Department of Information Management, Ankara - Turkey. She holds a BA, MLIS, and Ph.D. in library and information science. Dr Önal has also worked as a librarian, lecturer and advisor in the Ministry of National Education. Professionally she is interested in all aspects of school librarianship, and especially in education, evaluation of information services. 